\title{
Radish production under different shading screens and mulching
}

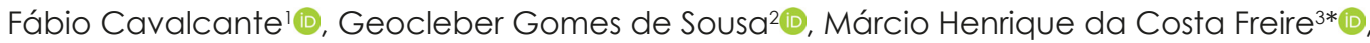 \\ Elizeu Matos da Cruz Filho ${ }^{2}$ (D), Rute Maria Rocha Ribeiro ${ }^{2}$ (i), Kelly Nascimento Leite ${ }^{4}$ (D) \\ 'Independent professional, Brasília, Brazil \\ 2University of International Integration of Afro-Brazilian Lusophony, Redenção, Brazil \\ ${ }^{3}$ Federal University of Ceará, Fortaleza, Brazil \\ ${ }^{4}$ Federal University of Acre, Cruzeiro do Sul, Brazil \\ *Corresponding author, e-mail: marciohcfreire@gmail.com
}

\begin{abstract}
Shading Screens and mulching may provide a favorable environment for radish growing in regions of adverse climates. This work aimed to evaluate the radish productivity under the influence of different shading screens associated with the presence and absence of mulch in two different years. The experiment was carried out in two different seasons (2017 dry season and 2018 rainy season), in the vegetable garden of Liberdade campus, at the University of International Integration of Afro-Brazilian Lusophony (Unilab), municipality of RedençãoCE. The experimental design was in randomized blocks in a split-plot arrangement, with four repetitions, in which the plots consisted of growing with and without mulching and in the subplots, five shading screens: $50 \%$ Black Shading Screen (50\% BSS), 50\% Red Shading Screen (50\% RSS), 30\% White Shading Screen (30\% WSS), $70 \%$ Black Shading Screen (70\% BSS) ), and full sunlight (FS). The red shading screens $50 \%$ and white $30 \%$, in addition to cultivation under full sunlight, provide higher performance in terms of the number of leaves, tuberous root diameter, tuberous root matter, and the radish crop productivity, regardless of the evaluated period. The applied mulch does not influence the productivity of the rabante, influencing only the gain of dry mass of the aerial part, soluble solids and length of the tuberous root.
\end{abstract}

Keywords: environmental conditions, Rapanhus sativus L., soil management

\section{Introduction}

In times when the days register high temperatures and higher luminosity, crop production can be affected due to the stress caused to the plants. One manner to minimize this problem is the use of coverings, such as those provided by shading screens, which allow different percentages of light penetration and installed in a foldable way (Santos et al., 2017).

Radish (Raphanus sativus L.), a short-cycle plant, produces globular roots, bright red in color and white pulp, in the most widely accepted cultivars (Filgueira, 2012). In the case of a culture that responds well to wavelengths in long days, requiring photoperiods to contribute to complete its cycle (Schuster et al., 2012). Lima et al. (2015) in their research with radish cultivars in two types of protected environments (white screen and $50 \%$ red screen), noted that the development of the culture was impaired when cultivated in an environment with $50 \%$ shading red screen compared to the obtained on the white screen, although the leaf area of the crop has increased.

Rampazzo et al. (2014) found that the use of shade structure reduces the minimum and maximum values concerning luminosity and air temperature and an increase in relative humidity when faced with the full sunlight environment. However, if the light flow is reduced to inadequate levels (above or below that required by the crops), a productivity decrease may occur (Santos et al., 2010). Tullio et al. (2013) obtained inferior results regarding the production characteristics of beet culture when it was grown in an environment with a $70 \%$ black screen compared to the cultivation in full sunlight during the summer.

Additionally, some strategies that lead to preserve soil characteristics, such as the use of mulch are on the rise in the scientific community, such as the application of 
crop residues, straw, and husks of carbonized rice (Rosa et al., 2014). Vegetable mulch has a significant effect on the survival of young plants, contributing to the reduction of soil temperature and in the humidity assurance around the plants for a longer period, with physical, chemical, and biological improvements (Harrison et al., 2013).

Santos ef al. (2012) evaluating the production of organically grown onions depending on the use of gliricidia mulch and castor bean cake, verified productivity benefits, and crop quality. The authors attributed this effect, probably, by the reduction of the thermal amplitude in the soil and higher humidity maintenance.

In this sense, this study aimed to evaluate the radish productivity under the influence of different shading screens, associated with the presence and the absence of mulch in two different periods.

\section{Material and Methods}

The experiment was carried out in two different periods: from November to December 2017 (dry season), and from February to March 2018 (rainy season), both in the didactic vegetable garden Professor Luís Antônio da Silva, at the University of International Integration of Afro-Brazilian Lusophony (Unilab), on Liberdade campus, Redenção, CE.
The municipality is located in the Maciço de Baturité region at latitude coordinates $4^{\circ} 13^{\prime} 33^{\prime \prime} \mathrm{S}$ and longitude $38^{\circ} 43^{\prime} 50^{\prime \prime} \mathrm{W}$, at an altitude of 88.8 meters (m). According to Köppen, the climate of the region is classified as Aw'. That is, rainy tropical, very warm with predominant rains in the summer and autumn seasons. Its average annual rainfall is estimated at $1,062 \mathrm{~mm}$, and a mean annual temperature of $25^{\circ} \mathrm{C}$.

The experiments were conducted in a randomized block design (RBD), in a split-plot arrangement, with four replications. The plots consisted of soil cover (with and without mulch) and in the subplots, environments with different shade screens: (black shading screen 50\% - 50\% BSS; red shading screen $50 \%$ - 50\% RSS; white shading screen $30 \%$ - 30\% WSS; black shading screen $70 \%-70 \%$ BSS; and full sunlight - FS). The screens used were arranged in four seedbeds with an area of $5 \times 1$ meter $(\mathrm{m})$ each. Then, screens were spaced $0.50 \mathrm{~m}$ apart to avoid light interference, with a ceiling height of $1.60 \mathrm{~m}$, and open on the sides.

For the soil chemical analyses, samples were collected at $0-20 \mathrm{~cm}$ depth, before applying the treatments in the experimental area (Table 1), following the methodology recommended by Teixeira et al. (2017). For the texture, the soil is characterized as sandy loam, with density of $1.4 \mathrm{~kg} \mathrm{dm}^{-3}$.

Table 1. Soil chemical characteristics before treatment application.

\begin{tabular}{|c|c|c|c|c|c|c|c|c|c|c|c|}
\hline \multicolumn{12}{|c|}{ Chemical attributes } \\
\hline$O M$ & $\mathrm{~N}$ & $\mathrm{Ca}^{2+}$ & $\mathrm{K}^{+}$ & $\mathrm{Mg}^{2+}$ & $\mathrm{Na}^{+}$ & $\mathrm{H}^{+}+\mathrm{Al}^{3+}$ & $\mathrm{Al}^{3+}$ & SB & $T$ & $\mathrm{~V}$ & $P$ \\
\hline \multicolumn{2}{|c|}{$\left(g^{\prime} g^{-1}\right)$} & \multicolumn{8}{|c|}{$\left(\mathrm{cmol}_{\mathrm{C}} \mathrm{Kg}^{-1}\right)$} & (\%) & $\left(\mathrm{mg} \mathrm{Kg}^{-1}\right)$ \\
\hline 8.38 & 0.53 & 2.5 & 0.29 & 2.2 & 45 & 1,32 & 0,05 & 49,99 & 51,3 & 97 & 26 \\
\hline
\end{tabular}

Radish variety used in the experiment was Vip Crimson, with sowing made through furrows. Then, seeds were manually dispensed into two furrows within each plot, with a spacing of $0.20 \times 0.10 \mathrm{~m}$, at a depth of 1 $\mathrm{cm}$, and keeping the same distance between them. Thinning was performed 10 days after sowing (DAS). The spacing used between them was $0.10 \mathrm{~m}$, following the recommended to the crop, with an average of 10 plants per each planting line.

After thinning, fertilization was carried out based on the recommendations by Filgueira (2012): 30 kilograms per hectare $\left(\mathrm{kg} \mathrm{ha}^{-1}\right)$ of nitrogen $(\mathrm{N})$ in the form of urea; $100 \mathrm{~kg} \mathrm{ha}^{-1}$ of phosphorus $(\mathrm{P})$ in the form of simple superphosphate; and $2 \mathrm{~kg} \mathrm{ha}^{-1}$ of boron (B) in the form of borax. The fertilizers were deposited uniformly on the crop lines.

At 15 DAS the application of mulch over the cultivated soil was initiated within the screened environments for the assessed periods. The cover used was rice husk, applied with a thickness of $5 \mathrm{~cm}$ in height.

The irrigation system adopted was the microsprinkler, using microjets as emitters, with a flow rate of 35 liters per hour $\left(L^{-1}\right)$, spaced 1.0 meters apart, arranged in a single polyethylene, hose placed in the center of each seedbed, parallel to its length. The water used for irrigation was non-saline, with an electrical conductivity of $0.3 \mathrm{dS} \mathrm{m}^{-1}$.

The irrigation was performed with a daily frequency, divided into two applications (in the morning and afternoon), in order to keep the soil in the field capacity, whose necessary water depth was estimated using the $\mathrm{Kc}$ of the crop and the reference evapotranspiration is determined by the "A" class tank. The crop water need can be calculated with the following equation:

$$
\mathrm{ETC}=\mathrm{ET}_{0} \times \mathrm{KC}
$$


On what: ETc = crop evapotranspiration, in millimeters per day $\left(\mathrm{mm} \mathrm{day}^{-1}\right)$; ETo: reference evapotranspiration ( $\left.\mathrm{mm} \mathrm{day}^{-1}\right)$; $\mathrm{Kc}$ : crop coefficient (for radish it is 0.70 for stage $1 ; 0.80$ for stage II; 0.90 for stage III and 0.85 for stage IV). During the rainy season, supplementary irrigation was not applied.

Meteorological data obtained during the experimental period are shown in Table 2, in which it is possible to observe a reduction in temperature inside the screened environments.

Table 2. Average Temperature $\left({ }^{\circ} \mathrm{C}\right)$ and Relative Humidity (\%) of shaded environments during the two cycles

\begin{tabular}{ccccc}
\hline \multirow{2}{*}{ Shading Screens } & \multicolumn{2}{c}{ Temperature $\left({ }^{\circ} \mathrm{C}\right)$} & \multicolumn{2}{c}{ Humidity (\%) } \\
\cline { 2 - 5 } & $2017^{\#}$ & $2018^{\# \#}$ & $2017^{\#}$ & $2018^{\# \#}$ \\
\hline FS & 34.2 & 30.5 & 44 & 62 \\
$50 \%$ BSS & 32.8 & 30.4 & 53 & 66 \\
$50 \%$ RSS & 32.9 & 30.3 & 52 & 65 \\
30\% WSS & 31.4 & 29.9 & 54 & 68 \\
70\% BSS & 30.7 & 29.4 & 44 & 70 \\
\hline \#= referring to the months of November and December; \#\# = for the months of February and March
\end{tabular}

At 35 DAS (dry season) and 40 DAS (rainy season), radish plants were harvested, and the following variables were assessed: the number of leaves - NL (adopting the direct count of the expansive leaves of each plant); leaf area - LA (in $\mathrm{cm}^{2}$, by the non-destructive method, using only one leaf, measured with the aid of a ruler and applying a radish correction factor of 0.57 (Matos et al., 2015); and dry matter of aerial part - DMAP (in g, after removing the aerial part of the radish, it was placed in bags identified according to the treatment and airdried in a protected environment until it lost all moisture, afterward weighing on a digital scale).

Regarding the commercial product, the following parameters were analyzed: root system length - RSL (in cm) and tuberous root - TRL (in mm) (the plant root was cut close to the part of the interest of the plant and measured with a ruler); tuberous root diameter - TRD (in $\mathrm{mm}$; using a digital caliper, in the center of the fruit); tuberous root matter - TRM (in g; obtained from the use of a digital scale); soluble solids - SS (in ${ }^{\circ}$ Brix; using a digital refractometer); and productivity - PROD (in T ha- ${ }^{-1}$; tuberous root was weighed in grams, and after quantification, the weight was transformed into kilos, and multiplied by the plant stand per hectare).

Results regarding the environments and the use of mulch were subjected to analysis of variance (ANOVA), and when significant, by the F test, the means were compared by the Tukey test, using the program ASSISTAT, version 7.7 Beta (Silva \& Azevedo, 2016). The results of the measurements followed by lowercase letters in the row and uppercase letters in the column do not differ significantly by the Tukey test at $5 \%$ probability.

\section{Results and Discussion}

Table 3 shows that there was a significant interaction among analyzed factors to the soluble solid variables ('Brix) and tuberous root length (TRL) just on the first cycle. Concerning the second cycle, only the screen factor influenced for these variables. Though, for the mulch factor, only the variable dry matter of the aerial part (DMAP) was significant for both cycles. While for the screened factor, the variables number of leaves (NL), dry matter of the aerial part (DMAP), tuberous root diameter (DRT), tuberous root matter (MRT), and productivity (PROD) reached significant values for both cycles.

Assessments regarding the variable number of leaves revealed that during the dry period the highest averages obtained were for $50 \%$ RSS (8), 30\% WSS (8) and FS (8) screens, showing that in these environments there was no difference statistics, as can be seen in Figure 1A. Whereas in the rainy season, the results of the $70 \%$ BSS, $50 \%$ BSS, 30\% WSS, and FS environments did not differ, being superior to the screen with $50 \%$ RSS (Figure 1B).

Oliari et al. (2010), in an experiment with radish, showed that the shading did not influence the number of leaves in relation to plants grown in full sunlight. Additionally, contrasting results to the present study were obtained by Schuster et al. (2012) when assessing the radish crop under reduced radiation and in full sunlight. They found a higher number of leaves for the crop when it was grown without solar radiation restrictions.

Concerning the environment factor, the greatest averages obtained for a dry matter of the aerial part (Figure 1C and 1D) in both evaluation periods occurred in the 50\% RSS and 30\% WSS (drought: 2.34 and 2.62 g; rainy season: 2.47 and $2.17 \mathrm{~g}$, respectively). However, about other environments, the results obtained were lower. This result shows that in these two shade (between 30-50\%), there was a higher accumulation of photoassimilates in the upper part of the plant, Presumably, it occurred due to the better light transmissivity that these environments provide, which led to better light absorption and better photosynthetic efficiencies, which influenced directly in a stress attenuation (Tatagiba et al., 2010; Taiz \& Zeiger, 2013).

Henrique et al. (2011) growing coffee seedlings (Coffea), found superior results compared to the dry matter of the leaves when they cultivated the seedlings under red shade screen. Different results were obtained by Ricardo et al. (2014) who grown lettuce in different shade screens (Aluminet, Cromatinet, and shade structure), and full sunlight (control). They found that the highest average 
obtained for the variable dry matter of the aerial part was in the full sunlight environment. The authors justified this fact because the planting season occurred in March when there was a decrease in solar radiation, in which the shade screens had the opposite effect on the crop: with low light, plants tended to etiolate in search of higher and better light availability.

Table 3. Summary of the analysis of variance for number of leaves (NF), dry matter aerial part (MSPA), root system length (RSL), tuberous root length (TRL), tuberous root diameter (TRD), tuberous root matter (TRM), soluble solids (SS) and productivity (PROD) of radish grown in different shade screens, with and without mulch.

\begin{tabular}{|c|c|c|c|c|c|c|c|c|c|}
\hline \multirow{2}{*}{ SV } & \multirow{2}{*}{ DF } & \multicolumn{8}{|c|}{ Mean square } \\
\hline & & $\mathrm{NL}$ & DMAP & RSL & TRL & TRD & TRM & SS & PROD \\
\hline \multicolumn{10}{|c|}{$1^{\circ} \mathrm{CYCLE}$} \\
\hline Mulch - a & 1 & $0.100^{\text {ns }}$ & $2.1139^{*}$ & $0.415^{\mathrm{ns}}$ & $156.934^{\mathrm{ns}}$ & $1.085^{\text {ns }}$ & $19.951^{\mathrm{ns}}$ & $0.289^{*}$ & $4987890.625^{\text {ns }}$ \\
\hline Resídual - a & 6 & 0.779 & 0.189 & 2.854 & 47.940 & 13.392 & 98.497 & 0.044 & 24624348.958 \\
\hline Screens - b & 4 & $2.359^{*}$ & $1.423^{* *}$ & $3.287^{\text {ns }}$ & $257.710^{* *}$ & $277.111^{* *}$ & $1494.654^{* *}$ & $0.082^{\text {ns }}$ & $373663671.875^{* *}$ \\
\hline Resídual - b & 24 & 0.560 & 0.16 & 1.902 & 19.163 & 9.682 & 50.023 & 0.046 & 12505859.375 \\
\hline Int. $a \times b$ & 4 & $0.303^{\text {ns }}$ & $0.045^{\text {ns }}$ & $0.865^{\mathrm{ns}}$ & $88.539^{* *}$ & $9.960^{\text {ns }}$ & $87.904^{\text {ns }}$ & $0.249^{* *}$ & $21976171.875^{\mathrm{ns}}$ \\
\hline Total & 39 & - & - & - & - & - & - & - & - \\
\hline$C V-a(\%)$ & - & 11.58 & 21.02 & 24.47 & 14.00 & 8.94 & 24.84 & 6.55 & 24.84 \\
\hline$C V-b(\%)$ & - & 9.82 & 19.36 & 19.98 & 8.85 & 7.60 & 17.70 & 6.69 & 17.70 \\
\hline \multicolumn{10}{|c|}{$2^{\circ} \mathrm{CYCLE}$} \\
\hline Mulch - a & 1 & $0.22^{\text {ns }}$ & $18.91^{*}$ & $1.34^{\mathrm{ns}}$ & $41.75^{\mathrm{ns}}$ & $49.15^{\text {ns }}$ & $39.68^{\text {ns }}$ & $0.06^{\text {ns }}$ & $4.87^{\mathrm{ns}}$ \\
\hline Resídual - a & 6 & 0.24 & 0.18 & 5.52 & 32.85 & 20.82 & 69.17 & 0.08 & 34922265.620 \\
\hline Screens - b & 4 & $1.29^{*}$ & $9.35^{* *}$ & $4.50^{\text {ns }}$ & $243.49^{* *}$ & $187.89^{* *}$ & $53.65^{* *}$ & $0.14^{* *}$ & $26345243.53^{* *}$ \\
\hline Resídual - b & 24 & 0.53 & 0.15 & 3.40 & 16.79 & 7.21 & 41.95 & 0.03 & 10489062.500 \\
\hline Int. $a \times b$ & 4 & $1.33^{\text {ns }}$ & $1.58^{\mathrm{ns}}$ & $0.21^{\mathrm{ns}}$ & $142.54^{\mathrm{ns}}$ & $69.66^{\mathrm{ns}}$ & $17.09^{n s}$ & $0.24^{\mathrm{ns}}$ & $1.32^{\text {ns }}$ \\
\hline Total & 39 & - & - & - & - & - & - & - & - \\
\hline$C V-a(\%)$ & - & 6.45 & 23.74 & 10.73 & 8.29 & 6.56 & 16.21 & 1.74 & 12.14 \\
\hline$C V-b(\%)$ & - & 9.61 & 18.82 & 9.41 & 11.58 & 11.14 & 20.80 & 6.90 & 19.47 \\
\hline
\end{tabular}

SV - Source of variation; DF - Degrees of freedom; CV - Coefficient of variation; ns - Not significant, ** and * - Significant at $p \leq 0.01$ and $p \leq 0.05$ by F test, respectively.
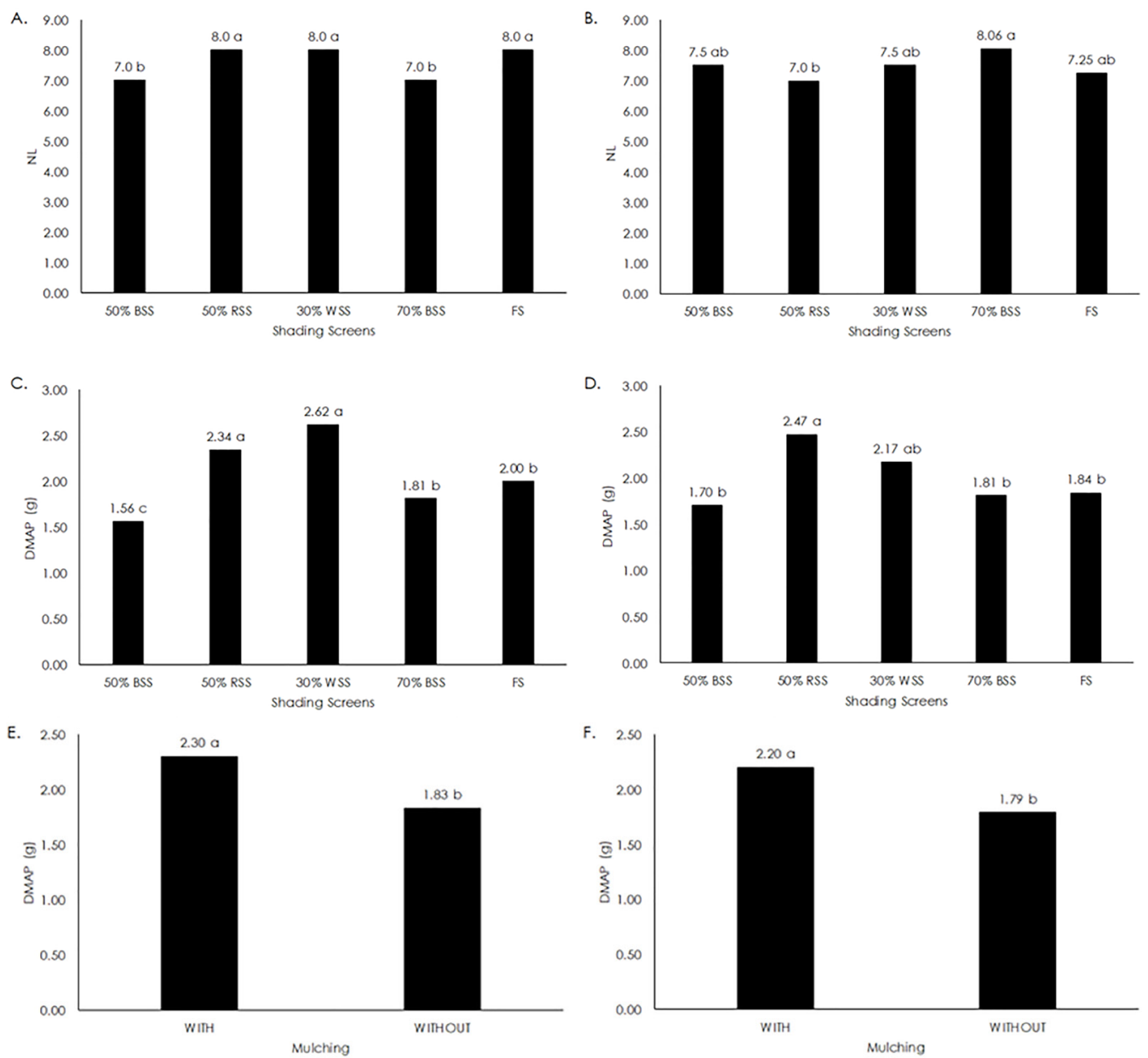

Figure 1. Number of leaves (NL) and dry matter aerial part (DMAP) of radish grown in soil with and without mulching in dry season ( $A, C$ and $E$ ) and rainy season (B, D and F). 
For the variable dry matter of the aerial part, there was an isolated effect for coverage factor at the level of significance at $1 \%$ for both evaluated periods. According to Figures $1 \mathrm{E}$ and $1 \mathrm{~F}$, the plants grown in the presence of mulch were statistically superior to those grown without the use of the mulch (2.3 and $2.2 \mathrm{~g}$, respectively), which might be justified by the mulch that keeping the wetter soil, which provides a reduction in temperature and allows the plant to accumulate more photoassimilates (Resende et al., 2005).

Santos et al. (2018), studying the effect soil cover on irrigated lettuce crop, during rainy season, found that there was a linear increase in dry matter of the aerial part of the crop caused by the increase in nitrogen doses, however with higher values for treatments with the presence of mulch compared to treatments without mulch. Similar results to the present study were recorded

by Ferreira et al. (2013), who studied the lettuce crop, noted that there was an increase in the dry matter of the aerial part when cultivated in soil with mulch.

According to Figure 2, the best averages for the variable tuberous root diameter were obtained in $50 \%$ RSS (42.97 mm), 30\% WSS (44.88 mm), and FS (47.32 mm), with no statistical difference between these averages. However, the lowest values were for 50\% BSS 133.64 $\mathrm{mm}$ ) and $70 \%$ BSS (35.95 $\mathrm{mm}$ ) during the dry season (A). Whereas, for the rainy season (B), the environments with $50 \%$ RSS, $30 \%$ WSS, $70 \%$ BSS, and FS did not differ statistically, reaching the highest averages $(38.9,36.26$, 35.95, and $39.11 \mathrm{~mm}$, respectively). The lowest result was observed for the screen with $50 \%$ BSS, with an average of $24.51 \mathrm{~mm}$, which differed statistically from the other environments.
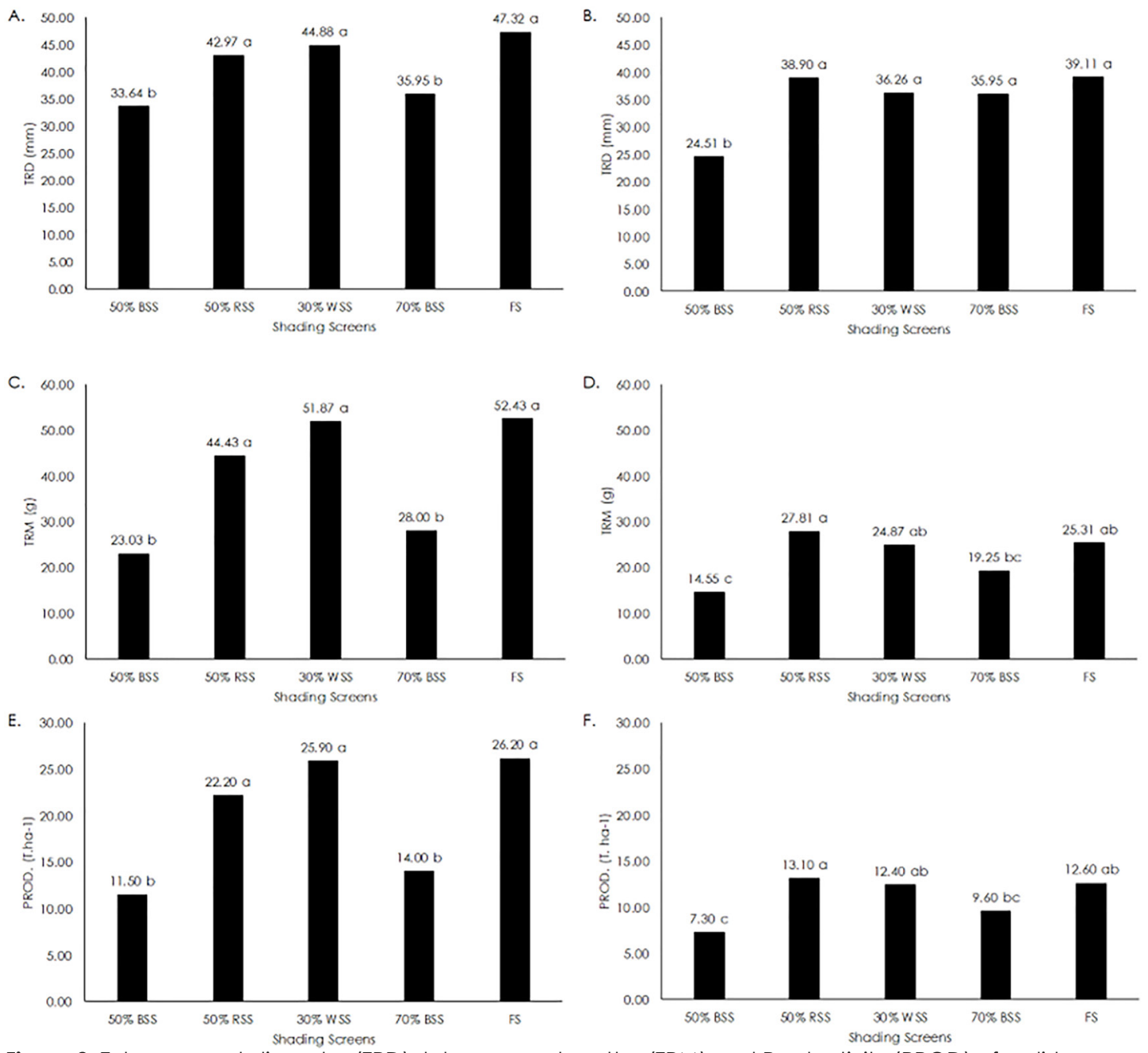

Figure 2. Tuberous root diameter (TRD), tuberous root matter (TRM) and Productivity (PROD) of radish grown under different shade screens in dry season ( $A, C$ and $E$ ) and rainy season (B, D and F).

The higher values reached during the dry season indicate that the crop had shortening of its production cycle, thus, starting to invest more in the development of the tuberous root, contrary to what could be observed in the rainy season (Taiz \& Zeiger, 2013), being the screened selection of wavelengths favorable to the culture, with the 
exception of the $50 \%$ BSS. Schneider et al. (2013) found that there was no statistical difference for the variable fruit diameter between different shade screens $130 \%$ and $50 \%$ ) in strawberry cultivars in the state of Paraná. Nonetheless, Dias et al. (2015) cultivating strawberry, concluded that the characteristic fruit diameter was higher in plants grown in full sunlight, being higher than plants grown in $50 \%$ shade screens.

In the variable tuberous root matter (Figure $2 \mathrm{C}$ ), during the dry season, the best averages were achieved in the FS (52.43 g), 30\% WSS (51.87 g), and 50\% RSS (44.43 g) treatments, however, these means had no statistical difference. Moreover, during the rainy season was observed that there were decreases for the crop when grown in the environment with $50 \%$ BSS (14.55 g), followed by $70 \%$ BSS (19.25 g), which did not differ statistically. The treatments with $30 \%$ WSS $(24.87 \mathrm{~g})$ and FS $(25.31 \mathrm{~g})$, obtained statistically similar averages, not differing from the highest mean found, $27.81 \mathrm{~g}$, in the environment with $50 \%$ RSS (Figure 2D). It is assumed that this result has been achieved due to plants grown in full sunlight have a lower accumulation of photoassimilates in the aerial part, allocating an amount to the tuberous root (Taiz \& Zeiger, 2013).

Confirming this result, Lima et al. (2015), cultivating radish on a $50 \%$ red shade screen, obtained a lower
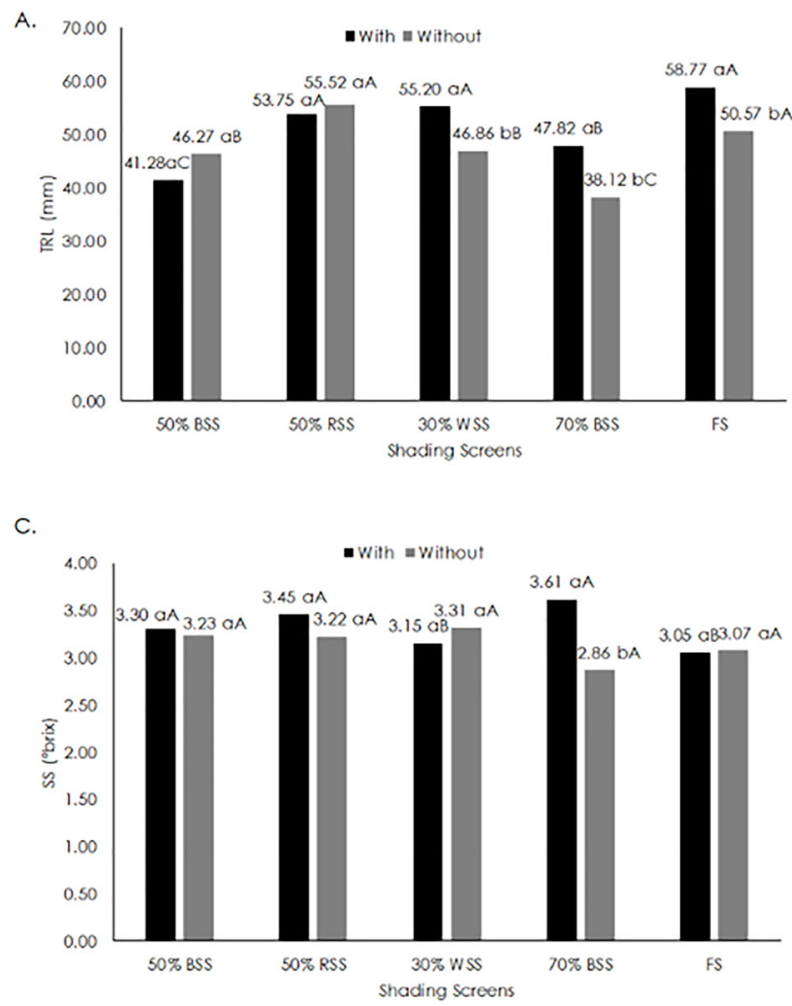

tuberous root matter when compared to cultivation under the white shade screen. However, Cabanez et al. (2015) found that the reduction in luminous intensity by 30,50 and $70 \%$ promoted less mass of the radish tuberous root.

Also, as observed in Figure $2 \mathrm{E}$ and $2 \mathrm{~F}$, the variable productivity presented the highest averages in FS, 30\% WSS, and 50\% RSS treatments, in both evaluated periods, so that during the rainy season the productivity averages were considerably below those obtained during the dry season.

Due to its characteristic of being a long-day plant, the crop, when cultivated during the rainy season, obtained lower yields than those obtained during the dry season, whose balance of radiation tends to be higher.

Figure $3 \mathrm{~A}$ represents the tuberous root length grown in the dry season. For the use of mulch, the best averages were in FS $(58.77 \mathrm{~mm}), 30 \%$ WSS $(55.2 \mathrm{~mm}$, and $50 \%$ RSS $(53.75 \mathrm{~mm})$ treatments, but these averages did not differ statistically between itself. However, for cultivation without mulch, the best averages were $50 \%$ RSS $(55.52 \mathrm{~mm})$ and FS $(50.57 \mathrm{~mm})$. Likely, this result reflects on the effect of the cover by providing a lower temperature in the soil, and thus a better microclimate for the plants, afterward, better stomatal regulation and a higher starch concentration (Resende et al., 2005).
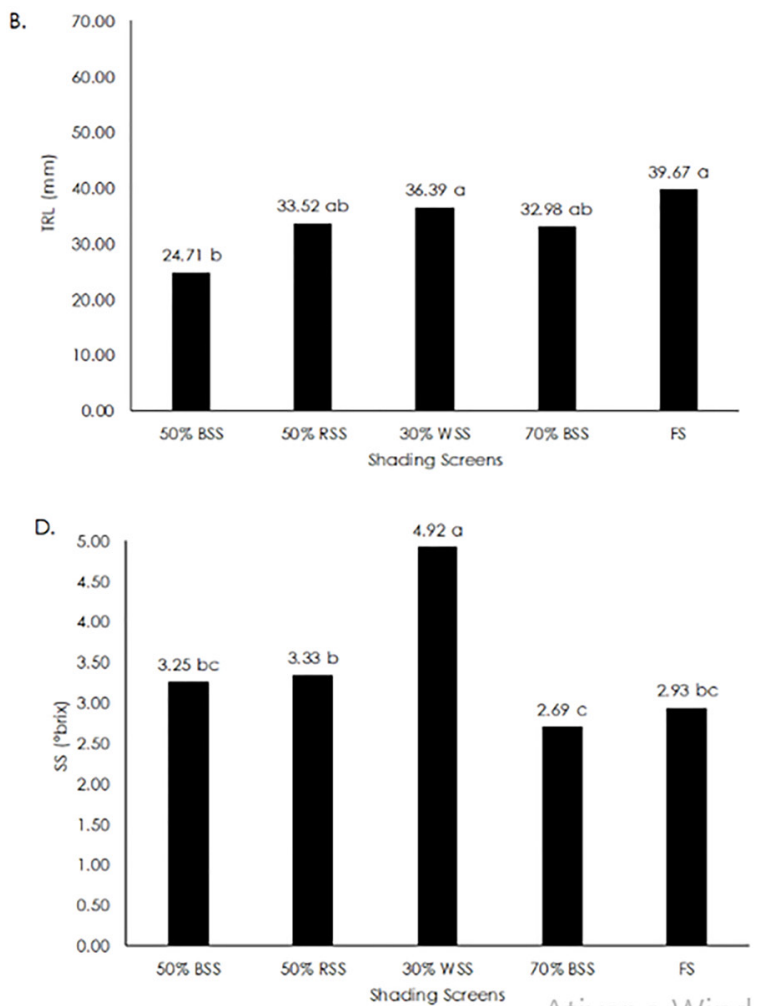

Figura 3. Tuberous root length (TRL) and soluble solids (SS) of radish grown under different shade screens in soil with and without mulch in dry season ( $A$ and $C$ ) and rainy season ( $B$ and $D$ ). 
Radish tuberous root length during the rainy season (Figure 3B) was longer when grown in full sunlight and under a screen with 30\% TSB, reaching means of 39.67 and $36.39 \mathrm{~mm}$, respectively, though, not differing statistically from each other. Also, environments with $50 \%$ RSS (33.52 mm) and 70\% BSS (32.98 mm) not differed statistically from the other treatments, however, it showed lower values than those obtained during the dry season. This result is possibly related to the shorter photoperiod compared to cultivation in the dry season and the higher heat retention on the environments with TSP, making the crop in hostile conditions to develop its root.

Lee \& Park (2020) evaluating the effects of colored plastic mulches on RZT and radish growth and yield in spring and fall plantings, found different results to the present study in that the coverage allowed a greater length of the tuberous root than when cultivated in bare soil. Results different from those too was obtained in this study described by Santos et al. (2011), in experiments growing carrots using different types of mulch (capim Cameroon (Pennisetum purpureum), gliricidia (Gliricidia sepium), and pigeonpea (Cajanus cajan)). That is, the use of mulch did not differ statistically from the control about tuberous root length.

For the variable soluble solids (Figures $3 \mathrm{C}$ and $3 D)$, it can be noticed that the best averages in crops with mulch were in the 70\% BSS (3.61), 50\% RSS (3.45), and $50 \%$ BSS (3.30) treatments in the dry season (C), and these values do not differ statistically. Whereas, for treatments without mulch, there was no statistical difference for any environment tested. When analyzing the averages of crops with and without covering, it was observed that in $70 \%$ BSS with coverage, there was a significant difference, showing the effect of this factor on the crop.

As it is known, temperatures accelerate the metabolic processes, and consequently, the consumption of photoassimilates increases, reducing the sugars availability in the fruit. It is noteworthy that this factor is reinforced because plants that grown under full sunlight breathe more and, therefore, release further $\mathrm{CO}_{2}$, thus reducing the sugars production (Taiz \& Zeiger, 2013). Results contrary to this study were gathered by Schneider et al. (2013), who studied the effect of different levels of shading on the strawberry crops, found that the highest content of soluble solids was obtained in the treatment with $0 \%$ shading, with $6.84^{\circ}$ Brix.

\section{Conclusions}

The red shading screens $50 \%$ and white $30 \%$ provide an increase in the dry matter of aerial part for the radish crop, regardless of the evaluated period.
The red shading screens $50 \%$ and white $30 \%$, in addition to cultivation under full sunlight provide higher performance in terms of the number of leaves, tuberous root diameter, tuberous root matter, and the radish crop productivity, regardless of the evaluated period.

Radish productivity is higher during the dry season compared to the rainy season.

The applied mulch does not influence the productivity of the rabante, influencing only the gain of dry mass of the aerial part, soluble solids and length of the tuberous root.

\section{References}

Cabanez, P.A., Pereira, L.R., Silva, S.F., Bernardes, C.O, Amaral, J.A.T. 2015. Interferência da radiação solar na cultura do rabanete. Nucleos 12: 257-262.

Dias, C.N., Marinho, A.B., Arruda, R.S., Silva, M.J.P., Pereira, E.D., Fernandes, C.N.V. 2015. Produtividade e qualidade do morangueiro sob dois ambientes e doses de biofertilizante. Revista Brasileira de Engenharia Agrícola e Ambiental 19: 961-966.

Ferreira, I.C.P.V., Araújo, A.V., Nascimento, A.L., Cavalcanti, T.F.M., Santos, L.D.T. 2013. Cobertura morta e adubação orgânica na produção de alface e supressão de plantas daninhas. Revista Ceres 60: 582-588.

Filgueira, F.A.R. 2012. Novo manual de olericultura. 3.ed. UFV, Viçosa, Brazil. 421 p.

Harrison, M.R., Spiers, J.D., Coneva, E.D., Dozier, W., Woods, F.M. 2013. Orchard design influences fruit quality, canopy temperature and yield of Satsuma mandrain (Citrus unshiu 'Owari'). International Journal of Fruit Science 13: 334-344.

Henrique, P.C., Alves, J.D., Deuner, S., Goulart, P.F.P., Livramento, D.E. 2011. Aspectos fisiológicos do desenvolvimento de mudas de café cultivadas sob telas de diferentes colorações. Pesquisa Agropecuária Brasileira 46: 458-465.

Lee, O.N., Park, H.Y. 2020. Effects of different colored film mulches on the growth and bolting time of radish (Raphanus sativus L.). Scientia Horticulturae 266: 109271.

Lima, E.M.C., Maller, A., Hara, A.T., Rezende, F.C., Carvalho, J.A. 2015. Efeito de diferentes níveis de água no solo na produção do rabanete cultivado em dois tipos de ambientes protegidos. Revista Engenharia na Agricultura 23: 346-354.

Matos, R.M., Silva, P.F., Lima, S.C., Santos, C.S., Dantas Neto, J. 2015. Características foliares e índice de colheita do rabanete irrigado com água residuária em ambiente protegido. Enciclopédia Biosfera 11:372-386.

Oliari, I.C., Umburanas, R.C., Eschemback, V., Kawakami, J. 2010. Efeito da restrição de luz solar e aumento da temperatura no crescimento de plantas de rabanete. Revista Pesquisa Aplicada \& Agrotecnologia 3: 85-96. 
Rampazzo, R., Seabra Júnior, S., Nunes, M.C.M, Neves, S.M.A.S., Ferreira, R.F. 2014. Eficiência de telas termorefletoras e de sombreamento em ambiente protegido tipo telado sob temperaturas elevadas. Revista Engenharia na Agricultura 22: 33-42.

Resende, F.V., Souza, L.S., Oliveira, P.S.R., Gualberto, R. 2005. Uso de cobertura morta vegetal no controle da umidade e temperatura do solo, na incidência de plantas invasoras e na produção da cenoura em cultivo de verão. Ciência agrotecnica 29: 100-105.

Ricardo, A.S., Vargas, P.F., Ferrari, S., Pavarini, G.M.P. 2014. Telas de sombreamento no desempenho de cultivares de alface. Nucleus 11: 433-442.

Rosa, D.D., Silva, D.F., Villa, F., Bueno, T.F., Corbari, F., Lucini, J. 2014. Qualidade de frutos de morangueiro sob diferentes condições de sombreamento e tipo de mulching no oeste do Paraná. Scientia Agraria Paranaensis 13: 126-132.

Santos, L.L., Seabra Júnior, S., Nunes, M.C.M. 2010. Luminosidade, temperatura do ar e do solo em ambientes de cultivo protegido. Revista de Ciências Agro-Ambientais 8: 83-93.

Santos, C.A.B., Zandoná, S.R., Espindola, J.A.A., Guerra, J.G.M., Ribeiro, R.L.D. 2011 . Efeito de coberturas mortas vegetais sobre o desempenho da cenoura em cultivo orgânico. Horticultura Brasileira 29: 103-107.

Santos, S.S., Espíndola, J.A.A., Guerra, J.G.M., Leal, M.A.A., Ribeiro, R.L.D. 2012. Produção de cebola orgânica em função do uso de cobertura morta e torta de mamona. Horticultura Brasileira 30: 549-552.

Santos, T.V., Lopes, T.C., Silva, A.G., Paula, R.C.M., Costa E., Binotti, F.F.S. 2017. Produção de mudas de maracujá amarelo com diferentes materiais refletores sobre bancada. Revista de Agricultura Neotropical 4: 26-32.

Santos, J.R.C., Fernandes, C.N.V., Oliveira Filho, J.N., Silva, A.R.A., Fernandes, J.N.V., Saraiva, K.R. 2018. Adubação nitrogenada e cobertura do solo no cultivo da alface irrigada. Revista Brasileira de Agricultura Irrigada 12: 23272337.

Schneider, R.P., Echer, M.M, Dalastra, G.M., Fiametti, M.S., Hachmann, T.L., Villa, F. 2013. Produtividade e qualidade de morangueiros submetidos ao sombreamento no Oeste do Paraná. Revista Cultivando o Saber 6: 56-66.

Schuster, M.Z., Kawakami, J., Broetto, D., Szymczak, L.S., Ramalho, K.R.O. 2012. Influência do fotoperíodo e da intensidade de radiação solar no crescimento e produção de tubérculos de rabanete. Pesquisa Aplicada \& Agrotecnologia 5: 73-86.

Silva, F.A.S., Azevedo, C.A.V. 2016. The Assistat Software Version 7.7 and its use in the analysis of experimental data. Africa Journal Agriculture Research 11: 3733 - 3740.

Taiz, L., Zeiger, E. 2013. Fisiologia vegetal. 5.ed. Artemed, Porto Alegre, Brazil. 954p.

Tatagiba, S.D., Pezzopane, J.E.M., Reis, E.F. 2010.
Crescimento vegetativo de mudas de café arábica (Coffea arábica L.) submetidas a diferentes níveis de sombreamento. Coffee Science 5: 251-261.

Teixeira, P.C., Donagemma, G.K., Fontana, A., Teixeira, W.G. 2017. Manual de métodos de análise de solo. 3.ed. Embrapa Informação Tecnológica, Brasília, Brazil. 573p.

Tullio, J.A., Otto, R.F., Boer, A., Ohse, S. 2013. Cultivo de beterraba em ambientes protegido e natural na época de verão. Revista Brasileira de Engenharia Agrícola e Ambiental 17: 1074-1079.

Conflict of Interest Statement: The authors declare that the research was conducted in the absence of any commercial or financial relationships that could be construed as a potential conflict of interest.

All the contents of this journal, except where otherwise noted, is licensed under a Creative Commons Attribution License attribuition-type BY. 